\title{
Benign Cardiac Germ Cell Tumor
}

National Cancer Institute

\section{Source}

National Cancer Institute. Benign Cardiac Germ Cell Tumor. NCI Thesaurus. Code C5357.

A non-metastasizing germ cell tumor that arises within the myocardium or cardiac

chambers. 